\title{
OCCUPATIONAL EXPOSURE TO DIISOCYANATES IN POLYURETHANE FOAM FACTORY WORKERS
}

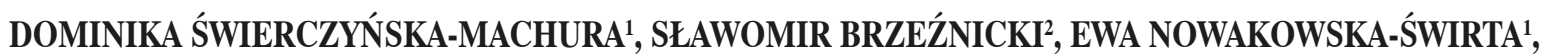 \\ JOLANTA WALUSIAK-SKORUPA ${ }^{1}$, TOMASZ WITTCZAK ${ }^{3}$, WOJCIECH DUDEK ${ }^{4}$, MARZENA BONCZAROWSKA ${ }^{2}$, \\ WIKTOR WESOŁOWSKI ${ }^{2}$, SŁAWOMIR CZERCZAK ${ }^{2}$, and CEZARY PAŁCZYŃSKI ${ }^{1}$
}

\author{
${ }^{1}$ Nofer Institute of Occupational Medicine, Łódź, Poland \\ Department of Occupational Diseases and Toxicology \\ ${ }^{2}$ Nofer Institute of Occupational Medicine, Łódź, Poland \\ Department of Chemical Safety \\ ${ }^{3}$ The Regional Centre for Occupational Medicine, Łódź, Poland \\ ${ }^{4}$ Dr Karol Jonscher City Hospital, Łódź, Poland \\ Department of Internal Medicine
}

\begin{abstract}
Objectives: The aim of the study was to evaluate health effects of occupational exposure to diisocyanates (DIC) among polyurethane foam products factory workers. Material and Methods: Thirty workers had a physical examination, skin prick tests with common allergens, allergen-specific immunoglobulin E ( $\operatorname{IgE})$ antibodies to diisocyanates and pulmonary function tests. Concentrations of selected isocyanates in the workplace air samples as well as concentration of their metabolites in the urine samples collected from the workers of the plant were determined. Results: The most frequent work-related symptoms reported by the examined subjects were rhinitis and skin symptoms. Sensitization to at least 1 common allergen was noted in $26.7 \%$ of the subjects. Spirometry changes of bronchial obstruction of a mild degree was observed in 5 workers. The specific IgE antibodies to toluene diisocyanate (TDI) and 4,4'-methylenebis(phenyl isocyanate) (MDI) were not detected in any of the patients' serum. Cellular profiles of the collected induced sputum (ISP) did not reveal any abnormalities. Air concentrations of TDI isomers ranged 0.2-58.9 $\mu \mathrm{g} / \mathrm{m}^{3}$ and in 7 cases they exceeded the Combined Exposure Index (CEI) value for those compounds. Concentrations of TDI metabolites in post-shift urine samples were significantly higher than in the case of pre-shift urine samples and in 6 cases they exceeded the British Biological Monitoring Guidance Value (BMGV - 1 umol amine/mol creatinine). We didn't find a correlation between urinary concentrations of TDI, concentrations in the air and concentrations of toluenediamine (TDA) in the post shift urine samples. Lack of such a correlation may be an effect of the respiratory protective equipment use. Conclusions: Determination of specific IgE in serum is not sensitive enough to serve as a biomarker. Estimation of concentrations of diisocyanate metabolites in urine samples and the presence of work-related allergic symptoms seem to be an adequate method for occupational exposure monitoring of DIC, which may help to determine workers at risk as well as to recognize hazardous workplaces.
\end{abstract}

Key words:

Biomarkers, Diisocyanates, Asthma, Polyurethanes, Biological monitoring, Occupational exposure, Occupational diseases

\footnotetext{
Financial support for this work was obtained from local statutory funds IMP 11.4 "Assessment of the health effects of inhalation exposure to diisocyanates among factory workers polyurethane foam" (grant manager: Dominika Świerczyńska-Machura, MD, Ph.D) and IMP 4.8 entitled "Evaluation of reliability of chosen isocyanates determinations in the air of workplace based on the biological monitoring of their metabolites eliminated with urine" (grant manager: Sławomir Brzeźnicki, Ph.D). Received: April 3, 2014. Accepted: January 24, 2015.

Corresponding author: D. Świerczyńska-Machura, Nofer Institute of Occupational Medicine, Department of Allergology and Environmental Health, św. Teresy 8 , 91-348 Łódź, Poland (e-mail: mika@imp.lodz.pl).
} 


\section{INTRODUCTION}

Diisocyanates (DIC), such as: toluene diisocyanate (TDI), 4,4'-methylenebis(phenyl isocyanate) (MDI) and hexamethylene diisocyanate (HDI), are commonly used in manufacture of many products, including flexible and rigid polyurethane foams, polyurethane rubbers and elastomers, adhesives, paints, coatings, insecticides, and rock consolidation media [1,2].

Diisocyanates at high concentrations can have direct toxic effects on mucous membranes or can act at low concentrations as sensitizing agents after binding to different proteins. Concentration of isocyanate as low as $1 \mathrm{ppm}$ has been confirmed to induce significant functional changes in humans and inflammation processes in the lung tissues [3].

Diisocyanates are still an important cause of occupational asthma in most industrialized countries, with a prevalence rate of 2.9-13\% [4,5]. Inhalation of diisocyanate vapours is also associated with numerous pulmonary disorders, such as eosinophilic airway inflammation, airway hyperresponsiveness and hypersensitivity pneumonitis $[4,6,7]$. Clinical diagnosis and the differential identification of isocyanates as the cause of work-related disorders are often difficult because of complexity of exposures. Exposure monitoring may recognize risk factors for a disease development and help prevent the onset or aggravation of the disease [8,9]. Efficient methods are needed to improve both primary preventive measures and surveillance of the exposed workers.

The route of exposure largely depends on workplace conditions, especially concentration and temperature during the manufacturing process. It is believed that allergy to diisocyanates occurs primarily via the respiratory system. However, dermal exposure may also induce respiratory sensitization $[10,11]$. Depending on the requirements of the technological process, diisocyanates may occur as liquids, vapors or aerosols. That is why measurement of diisocyanate levels in the air is complicated and requires application of different sampling methods. Another important thing related to the evaluation of occupational exposure to DIC via inhalation route is possibility of respiratory protective equipment (RPE) use. Taking into account the mentioned above problems and possibility of additional skin adsorption of DIC, biological monitoring seems to be a better way for occupational exposure assessment or for identification of susceptible subjects among the exposed workers.

At present, biological monitoring of exposure to isocyanates is carried out based on the measurement of concentrations of the corresponding amines (4,4'-methylenedianiline - MDA, 2,4-toluenediamine - 2,4-TDA, 2,6-toluenediamine - 2,6-TDA and 1,6-hexanediamine - HDA) [12-23] in urine or determination of the adducts of diisocyanates with hemoglobin or albumin in blood [14,24-27].

Also the presence of specific immunoglobulin E ( $\operatorname{IgE}$ ) antibodies in serum is suggested as an indicator of exposure to diisocyanates [28]. For practical reasons (convenience and non-invasive sampling), determination of selected diamines in urine samples seems to be more useful for risk assessment related to occupational exposure to diisocyanates than measurements of DIC adducts in blood. Until now, biological monitoring hasn't been used in Poland for the purpose of evaluation of occupational exposure to DIC. Estimation of occupational exposure to selected isocyanates has been conducted solely on the basis of measurements of their concentration in the work atmosphere and on the comparison of the obtained results with the values of maximum admissible concentrations (MAC) valid in Poland.

The aim of the study was to assess, for the first time in Poland, occupational exposure to DIC using environmental and biological monitoring, and to evaluate health effects associated with exposure among polyurethane foam factory workers. 


\section{MATERIAL AND METHODS}

\section{Study group}

The study population consisted of 30 workers (male) who have been working in a plant manufacturing TDI-based flexible polyurethane (PUR) foam in continuous foam blocks. In the manufacturing process a technical mixture of TDI isomers (2,4-TDI and 2,6-TDI), and (in some cases) MDI is used. 4,4'-Methylenebis(phenyl isocyanate), however, was used during only 1 day for production of 4 blocks of PUR. The production process consists of the preparation of components for manufacturing, programming the proportion of each component and the foaming process, which takes place in a closed ventilated tunnel on a moving conveyor lined with craft paper. At the end of the tunnel, expanded block is periodically cut into 60 -m-long pieces. Foaming process requires periodic presence of some workers in the tunnel where the expansion process occurs (tunnel workers performing folding paper task or maintenance workers).

Because of high concentrations of diisocyanates, during their presence in the tunnel, the workers should wear respiratory protective equipment. Workers employed in production of polyurethane foam blocks are not assigned to perform specific tasks during their working week. Depending on the needs, each of them can perform various operations related to the production process.

\section{Questionnaire}

Each subject had a medical history collected to gain information on the possible respiratory symptoms, occupational exposure, history of atopy, the smoking status and exposure to domestic animal allergens.

A clinical examination was also performed in all the subjects.

\section{Skin prick tests}

Skin prick tests (SPT) were performed on the volar part of the forearm with common allergens, which included tree and grass pollens, Dermatophagoides pteronyssinus, Dermatophagoides farinae, Lepidoglyphus destructor, moulds and feathers (Allergopharma, Germany). The SPTs were performed according to the standardized techniques [29]. All SPTs included positive $(10 \mathrm{mg} / \mathrm{ml}$ histamine hydrochloride, Stallergenes, France) and negative controls (phenylated glycerol-saline, Stallergenes, France). The results were assessed after $15 \mathrm{~min}$. Positive reaction was defined as a wheal diameter of at least $3 \mathrm{~mm}$ in the absence of reaction to the diluent and in the presence of a positive reaction to histamine.

\section{The level of allergen-specific IgE antibodies (asIgE) in serum}

The allergen-specific IgE antibodies to TDI (k75) and to MDI (k76) (Phadia, Uppsala, Sweden) were evaluated in each patient's serum.

\section{Pulmonary function tests}

Resting spirometry using MasterScope PC spirometer equipment (Jaeger, USA) was performed in all the subjects (reference values for Caucasian population according to the European Respiratory Society - ERS).

Metacholine challenge was performed in selected persons according to Cockroft [30].

\section{Induced sputum analysis}

Cellular profiles of induced sputum (ISP) were analyzed in 18 workers. The whole process of collecting ISP has been described elsewhere [31].

\section{Air measurements of diisocyanates}

Air samples (individual samples: $\mathrm{N}=20$ ) for determination of diisocyanates (2,4-TDI, 2,6-TDI, MDI) were collected in the breathing zone of the workers using Gilian GilAir-3 personal samplers. Measurement period was always close to the nominal time or no less than $75 \%$ of the time of the 8-h work shift, according to the adopted uniform criteria for monitoring work environment [32]. 
Determinations of selected isocyanates were performed using high performance liquid chromatography (HPLC) with spectrofluorometric detection (FLD) and/or spectrophotometric detection (PAD) according to the fully validated, accredited method (the Polish Centre for Accreditation, Certificate No. 215) used in the Department of Chemical Hazards of the Nofer Institute of Occupational Medicine (NIOM) in Lodz, Poland.

Briefly, a known volume of air ( 200 1, 11/min) was passed through glass fiber filters coated with 1-(2-Pyridyl)piperazine (1-2-PP). Then the filters were extracted with mixture $(2 \mathrm{ml})$ of acetonitrile and dimethyl sulfoxide (9:1 v:v) on a rotary shaker $(1 \mathrm{~h})$. Extracts were transferred to the autosampler vial and analysed using the Waters Alliance 2695 HPLC system equipped with Waters 2475 FLD and Waters 2996 PAD detectors. Calibration standards were prepared on 1,2-PP coated filters spiked with subsequent dilutions of 2,4-TDI, 2,6-TDI and MDI derivatives mixture. After evaporation of the solvent, the filters were treated the same way as the sample filters. Analytical conditions are presented in Table 1.

\section{Determination of DIC metabolites in urine samples}

Urine samples for determination of diisocyanates metabolites (2,4-TDA, 2,6-TDA and MDA) were collected before and immediately after the shift into polypropylene cups pretreated with $1 \mathrm{~g}$ of citric acid. The samples were stored at $-20^{\circ} \mathrm{C}$ until an instrumental analysis. Determinations of concentrations of 2,4-TDI, 2,6-TDI and MDI metabolites were performed using the capillary gas chromatography with mass spectrometry $(\mathrm{GC} /$ MS) techniques, according to the method described by Williams for HDI metabolite determination [33] and adapted by Creely [34] and Budnik [35] for determination of TDI and MDI metabolites in urine. This method is also proposed by The Health and Safety Laboratory (Agency of the Health and Safety Executive) for determination of DIC metabolites in urine [36].
Table 1. Analytical conditions of diisocyanates determination by means of the high performance liquid chromatography (HPLC) method

\begin{tabular}{|c|c|}
\hline Analytical column & $\begin{array}{l}\text { Supelcosil LC-CN } \\
250 \times 3 \mathrm{~mm}, 5 \mu \mathrm{m}\end{array}$ \\
\hline Mobile phase & $\begin{array}{c}\text { acetonitrile : } \\
\text { ammonium acetate } \\
0.01 \mathrm{M}, \mathrm{pH}=5.5\end{array}$ \\
\hline \multicolumn{2}{|l|}{ Gradient [min] } \\
\hline 0 & $0: 100$ \\
\hline 22 & $55: 45$ \\
\hline 25 & $0: 100$ \\
\hline 35 & $0: 100$ \\
\hline Flow rate $[\mathrm{ml} / \mathrm{min}]$ & 0.4 \\
\hline Sample volume $[\mu l]$ & 10 \\
\hline Column temperature $\left[{ }^{\circ} \mathrm{C}\right]$ & 35 \\
\hline FLD lex/lem [nm] & $260 / 370$ \\
\hline $\mathrm{PAD}[\mathrm{nm}]$ & $200-400$ \\
\hline \multicolumn{2}{|l|}{ Working range $[\mu \mathrm{g} / \mathrm{ml}]$} \\
\hline TDI & $0.014-\mathrm{m}$ \\
\hline MDI & $0.06-\mathrm{m}$ \\
\hline \multicolumn{2}{|l|}{ RSD of the calibration curve [\%] } \\
\hline 2,6-TDA/2,4-TDI & $5.6 / 5.7$ \\
\hline MDI & 4.7 \\
\hline \multicolumn{2}{|l|}{$\mathrm{LOQ}[\mathrm{ng} / \mathrm{ml}]$} \\
\hline 2,6-TDI/2,4-TDI & $1 / 0.5$ \\
\hline MDI [ng/ml] & 9.0 \\
\hline Within-day precision of the method [\%] & $2.5-5.1$ \\
\hline
\end{tabular}

FLD - spectrophotometric detection; PAD - spectrophotometric detection; TDI - toluene diisocyanate; MDI - 4,4'-methylenebis(phenyl isocyanate); RSD - relative standard deviation; TDA - toluenediamine; LOQ - limit of quantification.

Briefly, $2 \mathrm{ml}$ of urine sample was hydrolysed in sealed tubes with $0.2 \mathrm{ml}$ of concentrated sulfuric acid $\left(90 \mathrm{~min}, 100^{\circ} \mathrm{C}\right)$. The cooled samples were then alkalyzed with $2 \mathrm{ml}$ of $10 \mathrm{M}$ sodium hydroxide and extracted with $4 \mathrm{ml}$ of diethylether. Three milliliters of the resulted extract were transferred to clean tubes and diethylether was evaporated $\left(\mathrm{N}_{2}\right)$ to dryness. To the residue, heptafluorobutyric anhydride (HFBA) (50 $\mu$ in $0.5 \mathrm{ml}$ toluene) was added 
Table 2. Analytical conditions of toluene diisocyanate (TDI) and 4,4'-methylenebis(phenyl isocyanate) (MDI) metabolites determination by means of the gas chromatography with mass spectrometry (GC/MS) method

\begin{tabular}{lc}
\hline \multicolumn{1}{c}{ Capillary column } & $\begin{array}{c}\text { ZB-5HT INFERNO } \\
30 \mathrm{~m}, \varnothing 0.25 \mathrm{~mm}, \\
\text { film } 0,25 \mu \mathrm{m}\end{array}$ \\
\hline Injection chamber & splitless \\
operation mode & 300 \\
initial temperature $\left[{ }^{\circ} \mathrm{C}\right]$ & 1 \\
sample volume $[\mu \mathrm{l}]$ & $100 / 2$ \\
temperature programs $\left[{ }^{\circ} \mathrm{C} / \mathrm{min}\right]$ & $240 / 10$ \\
& $300 / 20$ \\
& $300 / 11$ \\
Mass detector & 280 \\
transfer line temperature $\left[{ }^{\circ} \mathrm{C}\right]$ & 150 \\
ion source temperature $\left[{ }^{\circ} \mathrm{C}\right]$ & 150 \\
quadrupole temperature $\left[{ }^{\circ} \mathrm{C}\right]$ & chemical $(-)$ methane \\
ionization & $20-600$ \\
mass range (SCAN) (jam) & $462.00,488.10,494.05$, \\
mass range (SIM) (jam) & $542.10,570.05,582.15$ \\
Working range & \\
TDA/MDA [ug/l] & $0.125-2.5 / 0.2-4.0$ \\
RSD of the calibration curve & \\
2,6-TDA/2,4-TDA [\%] & $16.2 / 17.6$ \\
MDA [\%] & 18.3 \\
LOD [ng/l] & \\
2,6-TDA/2,4-TDA/MDA & \\
Within-day precision of the method $[\%]$ & \\
\hline
\end{tabular}

SIM - single ion monitoring; MDA - methylenedianiline; LOD - limit of detection.

Other abbreviations as in Table 1.

as a derivatizating agent and the reaction of derivatization was carried out in closed tubes for $1 \mathrm{~h}$ at $55^{\circ} \mathrm{C}$. After evaporation of the excess of HFBA, residue was dissolved in $0.1 \mathrm{ml}$ of toluene and transferred to the autosampler vial. Instrumental analyses were performed using a HP 6890N gas chromatograph equipped with HP 5973 mass detector. Calibration standards were prepared by spiking urine of the unexposed person with subsequent dilution of 2,4-TDA, 2,6-TDA (5 data points at range $0.125-2.5 \mathrm{ug} / \mathrm{l}$ ) and MDA (5 data points at range $0.2-4 \mathrm{ug} / \mathrm{l}$ ) mixture. So prepared solutions were treated the same way as the urine samples. All the analytical conditions are presented in Table 2.

\section{Determination of creatinine}

One milliliter of each urine sample was transferred to $2 \mathrm{ml}$ Eppendorf tubes, frozen and submitted for analysis to the SYNEVO Polska Medical Diagnostics Laboratory.

\section{Quality control}

Validation of DIC determination method was performed according to the rules described in the European Standard EN 482:2012 [37]. Validation steps covered determinations of recovery of DIC from sampling media, linearity, precision, quantitation and detection limits and sample storage. Extended uncertainty of the method calculated for the pre-analytical and analytical stages was $27 \%$.

The method for determination of DIC metabolites in urine has been partially validated (linearity, precision, detection limit), because we have assumed, that the former use of this method in the other already published works reporting relevant validation data, in combination with our use of similar analytical equipment and reagents causes that the method may be reliably applied in our assays. Limit of detection (LOD) for each metabolite was calculated according to the equation:

$$
\mathrm{LOD}=3 \times \frac{3 \times \mathrm{SD}_{\mathrm{R}}}{\mathrm{b}}
$$

where:

$\mathrm{SD}_{\mathrm{R}}$ - standard deviation of the response of the lowest standard from calibration range diluted 10 times, $b$ - the slope of the calibration curve. 
Extended uncertainty covering uncertainty associated with precisions of determinations, linearity, weighing accuracy, standards purity, sample storage and glassware characteristic calculated for this method was $21 \%$.

During analysis of DIC and their metabolites, after analysis of 20 study samples, one reagent sample and one control sample were determined.

\section{ETHICS}

The study protocol was approved by the local Biomedical Ethics Committee.

\section{STATISTICS}

The data were presented as mean \pm standard deviations $(\mathrm{M} \pm \mathrm{SD})$. Statistical analyses were performed using the non-parametric Mann-Whitney Rank Sum test. Correlations were assessed by the Pearson's rank method. A level of $p<0.05$ was considered as significant.

\section{RESULTS}

Thirty workers aged 23 to 58 were evaluated. The characteristics of the study group is shown in Table 3. Employment duration on the current work post was $9.63 \pm 8$.7 years. The prevalence of allergic symptoms is presented in Table 4. The most frequent symptoms reported by the examined subjects were: rhinitis $(\mathrm{N}=7,23.3 \%)$ and skin symptoms $(\mathrm{N}=5,16.7 \%)$.

Skin prick tests were performed in all the plant workers. Sensitization to at least 1 common allergen was observed in $26.7 \%$ of the subjects (Table 5). Grass pollens $(\mathrm{N}=5)$ and Dermatophagoides pteronyssinus $(\mathrm{N}=4)$ were the most frequent allergens that caused positive results.

Resting spirometry was carried out in all the 30 patients. Baseline values were normal in 25 persons (83.3\%). Spirometry changes of bronchial obstruction of a mild degree were observed in 5 workers. One of them has been earlier diagnosed as asthmatic. Metacholine challenge tests were performed in those 5 subjects. This test revealed non-specific
Table 3. Characteristics of the study group

\begin{tabular}{lc}
\hline \multicolumn{1}{c}{ Questionnaire data } & $\begin{array}{c}\text { Respondents } \\
(\mathrm{N}=30)\end{array}$ \\
\hline Age [years] & \\
range & $23-58$ \\
M \pm SD & $39.3 \pm 11.5$ \\
Smoking status [n (\%)] & \\
active smokers & $17(56.7)$ \\
ex-smokers & $9(30.0)$ \\
non-smokers & $4(13.3)$ \\
Family history of atopy [n (\%)] & $2(6.7)$ \\
Pets at home [n (\%)] & $15(50.0)$ \\
Place of living [n (\%)] & \\
town & $25(83.3)$ \\
country & $4(16.7)$ \\
Housing [n $(\%)]$ & \\
old & $9(36.7)$ \\
new & $19(63.3)$ \\
\hline
\end{tabular}

Table 4. The prevalence of the reported work-related symptoms in the study group

\begin{tabular}{lc}
\hline \multicolumn{1}{c}{ Symptom } & $\begin{array}{c}\text { Respondents } \\
(\mathrm{N}=30) \\
{[\mathrm{n}(\%)]}\end{array}$ \\
\hline Rhinitis & $7(23.3)$ \\
Conjunctivitis & $3(10.0)$ \\
Dyspnoea & $3(10.0)$ \\
Cough & $3(10.0)$ \\
Skin symptoms & $5(16.7)$ \\
At least 1 allergic symptom & $13(43.3)$ \\
\hline
\end{tabular}

bronchial hyperactivity (BHR) $\left(\mathrm{PC}_{20}=4 \mathrm{mg} / \mathrm{ml}\right)$ in 1 patient, who has never been treated for asthma. The specific IgE antibodies to TDI and MDI were not detected in any of the patients' serum.

Induced sputum samples from 18 workers were collected. Cellular profiles of ISP are shown in Figure 1. In each sample, the dust of unknown origin in macrophages has been observed. 
Table 5. The incidence of positive results of skin prick tests to common allergens

\begin{tabular}{lc}
\hline \multicolumn{1}{c}{ Positive skin prick test results } & $\begin{array}{c}\text { Respondents } \\
(\mathrm{N}=30) \\
{[\mathrm{n}(\%)]}\end{array}$ \\
\hline At least 1 common allergen & $8(26.7)$ \\
Dermatophagoides farinae & $2(6.7)$ \\
Dermatophagoides pteronyssinus & $4(13.3)$ \\
Feathers & - \\
Grass pollens & $5(16.7)$ \\
Tree pollens $\mathrm{I}^{1}$ & $3(10.0)$ \\
Tree pollens II ${ }^{2}$ & $1(3.3)$ \\
Moulds $\mathrm{I}^{3}$ & - \\
Moulds II & \\
Weeds & $3(10.0)$ \\
Lepidoglyphus destructor & $1(3.3)$ \\
\hline
\end{tabular}

${ }^{1}$ Allergens of alder, hazel, poplar, elm, willow.

${ }^{2}$ Allergens of birch, beech, oak, plane.

${ }^{3}$ Alternaria tenuis, Botrytis cinerea, Cladosporium herbarum, Culvularia lunata, Helminthosporium, Fusarium moniliforme.

${ }^{4}$ Aspergillus fumigatus, Mucor mucedo, Penicillium notatum, Pullularia pullulans, Rhizopus nigricans, Serpula lacrimans.

Twenty workers agreed to participate in the environmental and biological monitoring study. 4,4'-Methylenebis(phenyl isocyanate) was detected only in the samples collected in the manufacturing department, in which the MDI was used for the foam production. However, concentrations of the compound were below the lower limit of the working

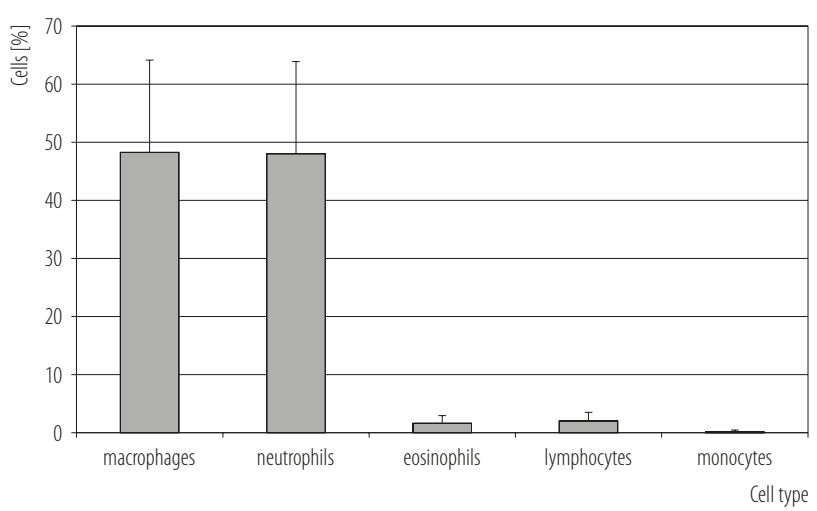

Fig. 1. Cellular profiles of induced sputum in the study group range $\left(0.0006 \mathrm{mg} / \mathrm{m}^{3}\right)$ of the analytical method. The results of 2,4-TDI and 2,6-TDI determinations in the workplace air during production of polyurethane foam blocks are presented in Table 6. The highest concentrations of TDI (sum of 2,4-TDI and 2,6-TDI isomers) were found in the work stations of the maintenance workers $\left(9.9-41.5 \mu \mathrm{g} / \mathrm{m}^{3}\right)$ and of paper folders $\left(0.3-58.7 \mu \mathrm{g} / \mathrm{m}^{3}\right)$. Lower concentrations of TDI were found in the samples collected from the work stations of foaming head operators $\left(0.6-11.3 \mu \mathrm{g} / \mathrm{m}^{3}\right)$ and cutting machine operators $\left(0.2-6.5 \mu \mathrm{g} / \mathrm{m}^{3}\right)$.

The results of TDI metabolites in the urine samples collected from the workers employed in the production of polyurethane foam blocks are shown in Figure 2 and in Table 6. Data presented in Figure 2 were expressed as $\mu \mathrm{g} / \mathrm{l}$ because concentration of creatinine in 8 samples of the pre-shift urine exceeded the accepted [38] range of $0.3-3 \mu \mathrm{g} / \mathrm{l}$.

A statistically significant increase in the concentrations of these metabolites in the samples collected at the end of the work shift, compared with the samples collected before the work shift was observed (Figure 3). Among the post-shift urine samples, only in 2 cases concentration of creatinine exceeded range of $0.3-3 \mu \mathrm{g} / \mathrm{l}$, therefore, urinary concentrations of TDI metabolites were adjusted to creatinine. The highest concentrations of TDI metabolites were found in the urine samples from the maintenance workers (geometric mean $(\mathrm{GM})=2.6 \mu \mathrm{mol} / \mathrm{mol}$ creatinine) and cutting machine operators ( $\mathrm{GM}=0.9 \mu \mathrm{mol} / \mathrm{mol}$ creatinine).

In $39 \%$ (7 of 18) of the post-shift urine samples, the TDI metabolite concentrations exceeded the Biological Monitoring Guidance Value (BMGV) of 1 umol TDA/ mol creatinine [39]. Taking into account all the obtained results, no correlation was found between the concentrations of diiisocyanate ( $\Sigma$ TDI isomers) in the air and the concentration of metabolites ( $\Sigma \mathrm{TDA}$ isomers) in the post shift urine samples $(r=0.051)$. However, a positive correlation $(r=0.84)$ was found for geometric means 
Table 6. Personal $8 \mathrm{~h}$ time weighted average (TWA) concentrations of toluene diisocyanate (TDI) in the air and its metabolites (TDA) in the post-shift urine samples of the monitored workers

\begin{tabular}{lcccc}
\hline \multirow{2}{*}{ Work place/task } & \multicolumn{2}{c}{$\begin{array}{c}\text { TDI concentration } \\
(2,4-\mathrm{TDI} \text { and 2,6-TDI) } \\
{\left[\mu \mathrm{g} / \mathrm{m}^{3}\right]}\end{array}$} & $\begin{array}{c}\text { TDA concentration } \\
\text { (2,4-TDA and 2,6-TDA) } \\
{[\mu \mathrm{mol} / \mathrm{mol} \text { creatinine }]}\end{array}$ \\
\cline { 2 - 5 } & range & $\mathrm{AM}(\mathrm{GM})$ & range & $\mathrm{AM}(\mathrm{GM})$ \\
\hline Foaming head operator $(\mathrm{N}=10)$ & $0.6-11.3$ & $3.7(1.8)$ & $<$ LOQ-1.9 & $0.6(0.3)$ \\
Cutting machine operator $(\mathrm{N}=3)$ & $0.2-6.5$ & $3.6(2.3)$ & $0.6-2.1$ & $1.1(0.9)$ \\
Maintenance workers $(\mathrm{N}=2)$ & $9.9-41.5$ & $25.7(20.2)$ & $1.7-3.9$ & $3.0(2.6)$ \\
Folding paper $(\mathrm{N}=5)$ & $0.3-58.7$ & $26.3(9.4)$ & $0.2-2.9$ & $1.0(0.7)$ \\
\hline
\end{tabular}

$\mathrm{AM}$ - arithmetic mean; GM - geometric mean; LOQ - limit of quantification.

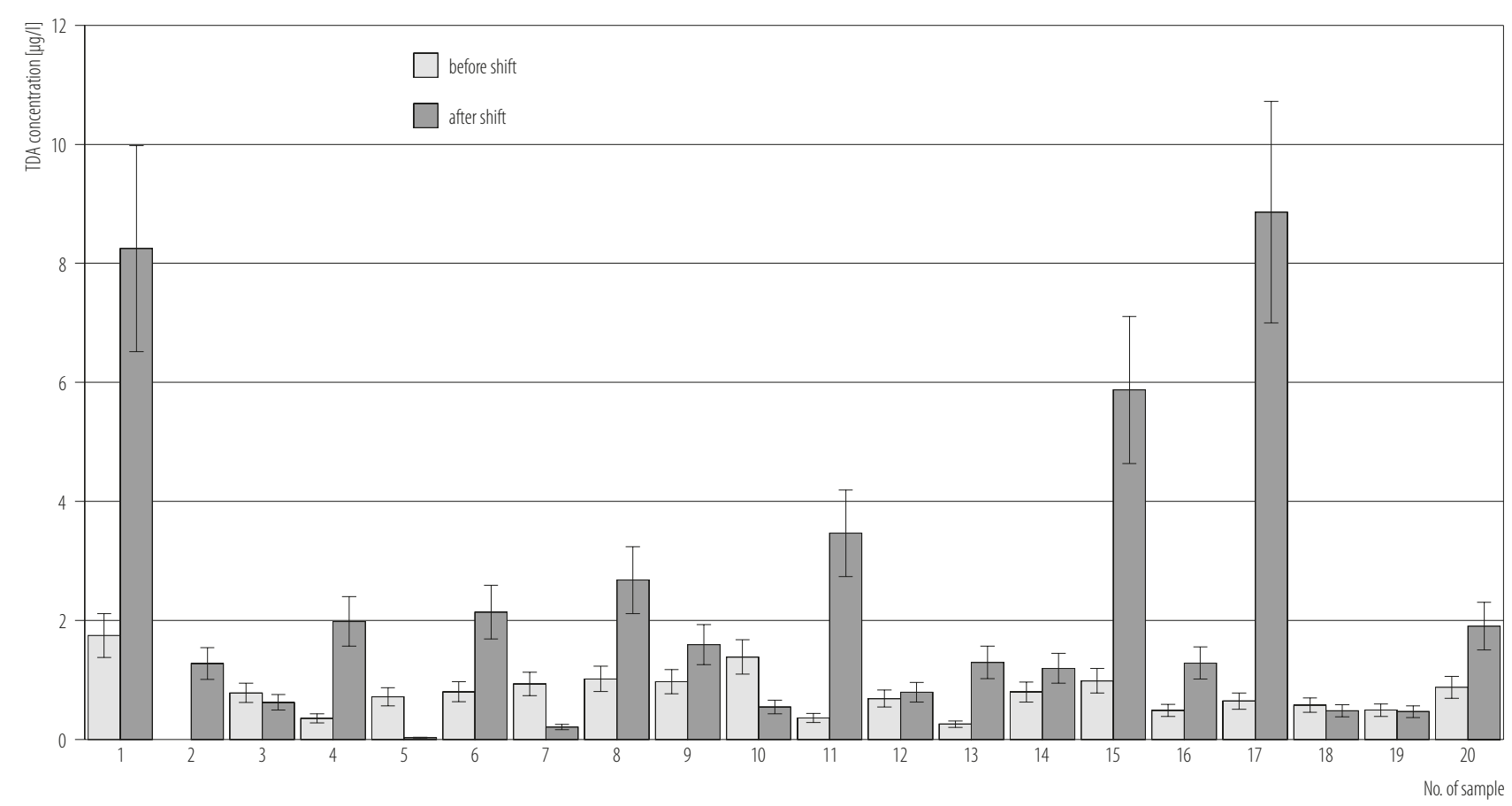

TDA - toluene.

Fig. 2. Estimation of diisocyanate metabolite concentrations (sum of 2,4-TDA and 2,6-TDA) in the urine samples collected from the workers employed in the production of polyurethane foam blocks

of TDI in the air and TDA in urine calculated for each of in the long-term follow up studies of diisocyanate-induced the worker groups.

\section{DISCUSSION}

Diisocyanates are one of the leading occupational causes of respiratory disorders, predominantly asthma. Because permanent impairment of lung function has been noted asthma (DA), the development of biomarkers to identify susceptible subjects among the exposed workers is essential. Only 5 to $10 \%$ of the exposed workers develop DA because a genetic predisposition plays a substantial role in the development of the disease. An important risk factor for the DA is the presence of certain polymorphisms associated with 


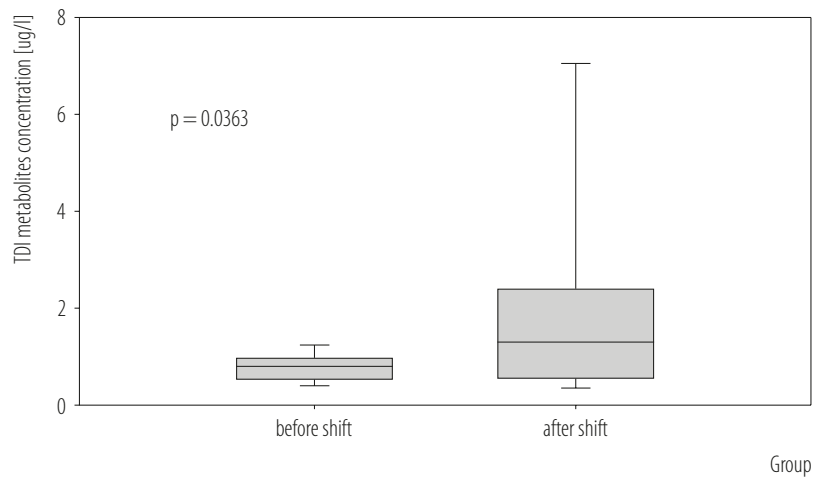

Fig. 3. Comparison of concentrations of TDI metabolites (sum of 2,4-TDA and 2,6-TDA) in the urine samples collected before and after the working shift

the xenobiotics metabolism, especially polymorphisms of genes encoding glutathione-S-transferase. It plays an important role in the efficiency of the elimination of diisocyanates form the body and therefore, might predict susceptibility for the induction of an allergic reaction [40].

Allergic asthma induced by diisocyanates is characterized by inflammation and airway hyperresponsiveness. Clinical symptoms of DA usually develop after a latency period from several months to several years after beginning of the exposure. Most patients suffer from asthma after cessation of exposure. Canadian authors [41] have shown that among 425 workers diagnosed with occupational asthma induced by diisocyanates the 1st symptoms of the disease appeared after 5 years. However, Orriols et al. [42] have found that this period was 16 months after working in diisocyanate exposure.

In our material, the mean employment duration was 9.6 years. At least 1 allergic symptom connected with work environment was reported in $43.3 \%$ of the study subjects. Among the examined respondents rhinitis and skin problems predominated. Hur et al. have noted work-related lower-respiratory symptoms in $22.4 \%$ of the subjects exposed to 4,4'-methylenebis(phenyl isocyanate) (MDI) in a car upholstery factory [43].

Frequency of sensitization to common allergens found on the basis of positive results of PTS in the analyzed material was $26.7 \%$ (8 subjects). This percentage is less than that seen in the general population, which is $37.8 \%$ [44]. Atopy as a risk factor for the diisocyanate-induced asthma has not been confirmed by other authors [2].

The specific IgE antibodies to TDI and MDI were not detected in the analyzed group of workers. Literature data show that $\mathrm{IgE}$ antibodies are present in about $5-30 \%$ of the patients with diagnosed diisocyanate-induced asthma, but also occasionally in workers without clinical symptoms [45,46].

Based on the material of the Nofer Institute of Occupational Medicine in 1999-2010, specific IgE antibodies were also not found among the patients exposed to diisocyanates in the workplace. Of 37 workers, 10 of them had the diisocyanate-induced asthma diagnosed [47].

Other authors have found the presence of serum specific $\mathrm{IgG}$ to toluene diisocyanate in some individuals with TDI-induced asthma, and thus, concluded IL-8 secreted by the activated neutrophils is responsible for bronchoconstriction [48].

High concentration of diisocyanate in the air of the working environment is a documented risk factor for both allergy and asthma [41].

Determination of the current value of hygienic standards for the majority of chemical compounds with a low molecular weight is connected with the relationship between the level of exposure and the health effects of these allergens. Even very low levels of allergen can provoke asthma symptoms in people who are allergic. Bernstein et al. [49] indicate that maintaining MDI at less than $0.005 \mathrm{ppm}$ in the working environment results in the low incidence of sensitization to MDI, and is associated with occupational asthma.

Results of many scientific studies indicate that, despite the low concentrations of isocyanates in the air, the level of metabolites in biological samples (urine, blood) collected from employees can be several times higher than 
the concentration of the compounds identified in the control groups $[24,50]$. Low concentrations of MDI in the air and corresponding urine metabolite - MDA found in our study, are probably due to the relatively low volume of PUR blocks produced with addition of MDI.

The results of our measurements of TDI concentrations in the workplace air were similar to the results of other authors obtained for the continuous foam block production $[21,24,51]$. Because of similar toxicological properties of 2,4-TDI and 2,6-TDI, the Combined Exposure Index (CEI), expressed as a sum of quotients of measured concentrations of particular chemicals and their MAC values, has been calculated. In 7 cases, CEI for TDI isomers was exceeded. The exceeded CEI values (CEI > 1) were found in the samples collected mainly from the workers who did the "paper folding" task or from the maintenance workers, whose activities require periodic presence in the tunnel where the foaming process takes place. During time of their work in the tunnel, (because of a high emission of isocyanate into the environment), these employees should wear respiratory protective equipment to minimize inhalation of harmful chemicals.

Occupational exposure to high concentrations of TDI isomers in the air resulted in a significant increase of the concentrations of TDI metabolites (2,4-TDA and 2,6-TDA) in the post shift urine samples, compared with those collected before the work shift. In some cases, however, high concentrations of TDI in the air did not correspond to high concentrations of their metabolites in urine (Table 6). Relatively low $(\mathrm{GM}=0.7 \mu \mathrm{mol} / \mathrm{mol}$ creatinine $)$ concentrations of TDA in urine of the workers who did the paper folding task compared to high concentrations of TDI in the air samples $\left(\mathrm{GM}=9.4 \mu \mathrm{g} / \mathrm{m}^{3}\right)$ collected in this group of workers may indicate effectiveness of the respiratory equipment worn during their presence in the tunnel. Protective equipment should be used also by the maintenance workers during tasks performed inside the tunnel. If so, higher concentration of TDA in the post-shift urine samples of the maintenance workers ( $\mathrm{N}=2, \mathrm{GM}=2.6 \mu \mathrm{mol} / \mathrm{mol}$ creatinine) could be explained as a result of additional skin adsorption.

As it was mentioned earlier, we didn't find a correlation between air concentration of TDI isomers and their metabolites in the post shift urine samples (individual results). In our opinion, lack of such a correlation may be due to the possibility of additional uptake of TDI through the skin or could be an effect of using personal protective equipment. The results of investigations carried out for such a process by Kaaira et al. [20] and Geens et al. [21] have shown good positive correlations between TDI concentrations in the air and TDA concentrations in urine. In both cases the authors have mentioned that the workers involved in the production process didn't wear any respiratory protective equipment [20] or that it was used inconsistently [21].

In 6 cases, concentrations of TDI metabolites in the pre shift urine samples were higher than in the samples collected at the end of the work shift. In our opinion, this may be a result of the earlier mentioned, interchangeability of jobs during the working week. The literature data concerning half-lives of metabolites of diisocyanates are not clear. The accessible data indicate that the half-lives of TDI metabolites are 2-5 h [18] or more than $26 \mathrm{~h}$ [21]. Budnik et al. [36] have found that in the case of exposure to high concentrations of TDI, the half-life amounted to $6 \mathrm{~h}$. The authors studying the kinetics of elimination of diisocyanate metabolites with urine have also noted that the urine samples collected immediately after completion of the work shift may contain only about $15-20 \%$ of the total amount of the excreted compounds.

Additionally, in the case of dermal absorption of diisocyanates, the distribution of metabolites (2,5-TDA) takes about $12 \mathrm{~h}$ and then the compound is eliminated from the body at $\mathrm{T}_{1 / 2}$ of $8 \mathrm{~h}[52]$.

Thus, it is likely that exposure to high concentrations of diisocyanates during the previous day of work can cause 
the elevated levels of their metabolites in the urine samples collected before the start of the work shift.

\section{CONCLUSIONS}

Reliable assessment of exposure is one of the essential factors needed for taking action for the purpose of occupational asthma prevention. For a proper assessment of occupational exposure to diisocyanates, results of biological monitoring should be analyzed together with the results of air monitoring. Determination of specific IgE in serum is not sensitive enough to serve as a biomarker, whereas assessment of the presence of work-related allergic symptoms seems to be more useful.

Because of an easy way of urine sampling and a still growing number of studies related to establishment of the Biological Guiding Value for diisocyanates [15,18,35,49] the quantification of their metabolites in urine samples seems to be an adequate method for monitoring occupational exposure to such compounds.

To the best of our knowledge, studies described above have been the 1st endeavor to use simultanoeusly biological and environmental monitoring for evaluation of health effects and occupational exposure to DIC in Poland. Taking into account data on the growing number of occupational asthma cases in the world, specificity of Polish polyurethane industry (a big number of small enterprises) and lack of information on working conditions in such companies, further continuation of similar studies seems to be justified.

\section{REFERENCES}

1. National Institute for Occupational Safety and Health. Preventing asthma and death from diisocyanate exposure. Public Health Service, CDC/NIOSH [cited 2014 Mar 30]. Available from: http://www.cdc.gov/niosh/docs/96-111.

2. Wisniewski AV, Redlich CA, Mapp CE, Bernstein DI. Polyisocyanates and their prepolymers. In: Bernstein IL, Chan-Yeung M, Malo JL, Bernstein DI, editors. Asthma in the workplace. 3rd edition. New York: Taylor and Francis Group; 2006. p. 481-504.

3. Lemière C, Romeo $\mathrm{P}$, Chaboillez S, Tremblay C, Malo J-L. Airway inflammation and functional changes after exposure to different concentrations of isocyanates. J Allergy Clin Immunol. 2002;110:641-6, http://dx.doi.org/10.1067/ mai.2002.128806.

4. Bernstein JA. Overview of diisocyanate occupational asthma. Toxicology. 1996;111:181-9, http://dx.doi.org/10.1016/0300483X(96)03375-6.

5. Ott MG, Klees JE, Poche SL. Respiratory health surveillance in a toluene diisocyanate production unit, 1967-97: Clinical observations and lung function analyses. Occup Environ Med. 2000;57:43-52, http://dx.doi.org/10.1136/oem.57.1.43.

6. Moscato G, Dellabianka A, Maestrelli P, Paggiaro P, Romano $\mathrm{C}$, de Zotti R, et al. Features and severity of occupational asthma upon diagnosis: An Italian multicentric case review. Allergy. 2002;57:236-42, http://dx.doi.org/10.1034/j.13989995.2002.103337.x.

7. Koperschmitt-Kubler MC, Ameille J, Popin E, CalastrengCrinquand A, Vervloet D, Bayeux-Dunglas MC, et al. Occupational asthma in France: A 1-yr report of the Observatoire National de Asthmes Professionnels project. Eur Respir J. 2002;19:84-9, http://dx.doi.org/10.1183/09031936.02.00102202.

8. Malo JL, Ghezzo H, Elie R. Occupational asthma caused by isocyanates: Patterns of asthmatic reactions to increasing day-to-day doses. Am J Respir Crit Care Med. 1999;159(6): 1879-83, http://dx.doi.org/10.1164/ajrccm.159.6.9806159.

9. Dykewicz MS. Occupational asthma: Current concepts in pathogenesis, diagnosis, and management. J Allergy Clin Immunol. 2009;123(3):519-28, http://dx.doi.org/10.1016/ j.jaci.2009.01.061.

10. Baur X. [Isocyanates: Occupational exposures and disorders]. Pneumologie. 2003;57:526-31, http://dx.doi.org/ 10.1055/s-2003-42221. German.

11. Baur X, Budnik LT. [New data on occupational exposure to isocyanates]. Pneumologie. 2009;63:656-61, http://dx.doi. org/10.1055/s-0029-1215098. German. 
12. Pearson RL, Logan PW, Kore AM, Strom CM, Brosseau LM, Kingston RL. Isocyanate exposure assessment combining industrial hygiene methods with biomonitoring for end users of orthopedic casting products. Ann Occup Hyg. 2013 Jul;57(6):758-65, http://dx.doi.org/10.1093/annhyg/mes110.

13. Jones K, Cocker J, Piney M. Isocyanate exposure control in motor vehicle paint spraying: Evidence from biological monitoring. Ann Occup Hyg. 2013 Mar;57(2):200-9, http:// dx.doi.org/10.1093/annhyg/mes056.

14. Sabbioni G, Wesp H, Lewalter J, Rumler R. Determination of isocyanate biomarkers in construction site workers. Biomarkers. 2007 Sep-Oct;12(5):468-83, http://dx.doi. org $/ 10.1080 / 13547500701395636$.

15. Sennbro CJ, Littorin M, Tinnerberg H, Jönsson BAG. Upper reference limits for biomarkers of exposure to aromatic diisocyanates. Int Arch Occup Environ Health. 2005;78:541-6, http://dx.doi.org/10.1007/s00420-005-0619-5.

16. Sennbro CJ, Lindh CH, Mattsson C, Jönsson BA, Tinnerberg $\mathrm{H}$. Biological monitoring of exposure to 1,5-naphthalene diisocyanate and 4,4'-methylenediphenyl diisocyanate. Int Arch Occup Environ Health. 2006 Sep;79(8):647-53, http://dx.doi.org/10.1007/s00420-006-0096-5.

17. Rosenberg C, Nikkilä K, Henriks-Eckerman ML, Peltonen K, Engström K. Biological monitoring of aromatic diisocyanates in workers exposed to thermal degradation products of polyurethanes. J Environ Monit. 2002 Oct;4(5):711-6, http://dx.doi.org/10.1039/b206340a.

18. Cocker J. Biological monitoring for isocyanates. Occup Med. 2007;57:391-6, http://dx.doi.org/10.1093/occmed/kql148.

19. Austin S. Biological monitoring of TDI-derived amines in polyurethane foam production. Occup Med (Lond). 2007 Sep;57(6):444-8, http://dx.doi.org/10.1093/occmed/kqm085.

20. Kääriä K, Hirvonen A, Norppa H, Piirilä P, Vainio H, Rosenberg C. Exposure to 2,4- and 2,6-toluene diisocyanate (TDI) during production of flexible foam: Determination of airborne TDI and urinary 2,4- and 2,6-toluenediamine (TDA). Analyst. 2001 Jul;126(7):1025-31, http://dx.doi.org/10.1039/ b102022f.
21. Geens T, Dugardin S, Schockaert A, de Cooman G, van Sprundel M. Air exposure assessment of TDI and biological monitoring of TDA in urine in workers in polyurethane foam industry. Occup Environ Med. 2012 Feb;69(2): 93-8, http://dx.doi.org/10.1136/oem.2011.064840.

22. De Palma G, Cortesi I, Ghitti R, Festa D, Bergonzi R, Apostoli P. Biological monitoring as a valid tool to assess occupational exposure to mixtures of 2,4-2,6-toluene diisocyanate. Med Lav. 2012 Sep-Oct;103(5):361-71.

23. Dalene M, Skarping G, Lind P. Workers exposed to thermal degradation products of TDI- and MDI-based polyurethane: Biomonitoring of 2,4-TDA, 2,6-TDA, and 4,4'-MDA in hydrolyzed urine and plasma. Am Ind Hyg Assoc J. 1997 Aug;58(8):587-91, http://dx.doi. org/10.1080/15428119791012522.

24. Säkkinen K, Tornaeus J, Hesso A, Hirvonen A, Vainio H, Norppa $\mathrm{H}$, et al. Protein adducts as biomarkers of exposure to aromatic diisocyanates in workers manufacturing polyurethane (PUR) foam. J Environ Monit. 2011 Apr;13(4):957-65, http://dx.doi.org/10.1039/c0em00595a.

25. Gries W, Leng G. Analytical determination of specific 4,4'-methylene diphenyl diisocyanate hemoglobin adducts in human blood. Anal Bioanal Chem. 2013 Sep;405(23): 7205-13, http://dx.doi.org/10.1007/s00216-013-7171-z.

26. Sabbioni G, Gu Q, Vanimireddy LR. Determination of isocyanate specific albumin-adducts in workers exposed to toluene diisocyanates. Biomarkers. 2012 Mar;17(2):150-9, http://dx.doi.org/10.3109/1354750X.2011.645166.

27. Lind P, Dalene M, Lindström V, Grubb A, Skarping G. Albumin adducts in plasma from workers exposed to toluene diisocyanate. Analyst. 1997 Feb;122(2):151-4, http://dx.doi. org/10.1039/a605700d.

28. Redlich CA, Homer RJ, Smith BR, Wirth JA, Cullen MR. Immunologic responses to isocyanates in sensitized asthmatic subjects. Chest. 1996;109:6-8.

29. Dreborg S, Frew AJ. Allergen standardization and skin tests. Allergy. 1993;48 Suppl 14:49-82, http://dx.doi. org/10.1111/j.1398-9995.1993.tb04756.x. 
30. Cockroft DW, Killinn DN, Mellon JJ, Hargreave FE. Bronchial reactivity to histamine: A method and clinical survey. Clin Allergy. 1977;7:235-43, http://dx.doi. org/10.1111/j.1365-2222.1977.tb01448.x.

31. Krakowiak A, Krawczyk-Adamus P, Dudek W, Walusiak J, Pałczyński C. Changes in cellular and biochemical profiles of induced sputum after allergen-induced asthmatic response: Method for studying occupational allergic airway inflammation. Int J Occup Med Environ Health. 2005;18(1):27-33.

32. PN-Z-04008-7:2002. [Air purity protection. Sampling methods. Principles of air sampling in work environment and interpretation of results]. Warszawa: Polish Committee for Standardization; 2002. Polish.

33. Williams NR, Jones K, Cocker J. Biological monitoring to assess exposure from use of isocyanates in motor vehicle repair. Occup Environ Med. 1999;56:598-601, http://dx.doi. org/10.1136/oem.56.9.598.

34. Creely KS, Hughson GW, Cocker J, Jones K. Assessing isocyanate exposures in polyurethane industry sectors using biological and air monitoring methods. Ann Occup Hyg. 2006 Aug;50(6):609-21, http://dx.doi.org/10.1093/annhyg/mel024.

35. Budnik LT, Nowak D, Merget R, Lemiere C, Baur X. Elimination kinetics of diisocyanates after specific inhalative challenges in humans: Mass spectrometry analysis, as basis for biomonitoring strategies. J Occup Med Toxicol. 2011;6:1-9, http://dx.doi.org/10.1186/1745-6673-6-9.

36. Health and Safety Laboratory. Biological monitoring methods. Method for isocyanate metabolites in urine. Buxton: Health and Safety Laboratory; 2005 [cited 2014 Mar 30]. Available from: http://www.hsl.gov.uk/media/1589/isocyanate_metab.pdf.

37. PN-EN 482:2012. [Workplace exposure. General requirements for the performance of procedures for the measurement of chemical agents]. Warszawa: Polish Committee for Standardization; 2012. Polish.

38. American Conference of Governmental Industrial Hygienists. Treshold limit values for chemical substances and physical agents and biological exposure indices. Cincinnati $(\mathrm{OH})$ :
American Conference of Governmental Industrial Hygienists; 2011.

39. Health and Safety Executive. Watch Committee. Biological monitoring for isocyanates. October 2005 [cited 2014 Apr 29]. Avaliable from: http://www.hse.gov.uk/aboutus/ meetings/iacs/acts/watch/051005/13.pdf.

40. Broberg KE, Warholm M, Tinnerberg H, Axmon A, Jonsson BA, Sennbro CJ, et al. The GSTP1 Ile 105 Val polymorphism modifies the metabolism of toluene di-isocyanate. Pharmacogenet Genomics. 2010;20:104-11, http://dx.doi. org/10.1097/FPC.0b013e328334fb84.

41. Tarlo SM, Liss GM, Yeung KS. Changes in rates and severity of compensation claims for asthma due to diisocyanates: A possible effect of medical surveillance measures. Occup Environ Med. 2002;59:58-62, http://dx.doi.org/10.1136/oem.59.1.58.

42. Orriols R, Drobnic ME, Munoz X, Rodrigo MJ, Morell F. Occupational asthma due to isocyanates: A study of $21 \mathrm{pa}-$ tients. Med Clin (Barc). 1999;113:659-62.

43. Hur GY, Koh DH, Choi GS, Park HJ, Choi SJ, Ye YM, et al. Clinical and immunologic findings of methylene diphenyl diisocyanate-induced occupational asthma in a car upholstery factory. Clin Exp Allergy. 2008;38:586-93, http://dx. doi.org/10.1111/j.1365-2222.2008.02935.x.

44. Faniran AO, Peat JK, Woolcock AJ. Prevalence of atopy, asthma symptoms and diagnosis, and the management of asthma: Comparison of affluent country. Thorax. 1999;54(7): 606-10, http://dx.doi.org/10.1136/thx.54.7.606.

45. Pieter SJ. MHC class II restricted antigen presentation. Curr Opin Immunol. 1997;9:89-96, http://dx.doi.org/10.10 16/S0952-7915(97)80164-1.

46. Kuchroo VK, Das MP, Brown JA, Ranger AM, Zamvil SS, Sobel RA, et al. B7-1 and B7-2 costimulatory molecules activate differentially disease therapy. Cell. 1995;80:707-18, http://dx.doi.org/10.1016/0092-8674(95)90349-6.

47. Świerczyńska-Machura D, Walusiak-Skorupa J, Wiszniewska M, Lipińska-Ojrzanowska A, Wittczak T, Dudek W, et al. [The real value of diagnostic methods in case of long time of cessation of occupational exposure to diisocyanates 
among patients diagnosed in the Nofer Institute of occupational medicine in Łódź]. Med Pr. 2011;62(6):567-77. Polish.

48. Park HS, Kim HY, Nahm DH, Son JW, Kim YY. Specific $\operatorname{IgG}$ but not specific IgE antibodies to toluene diisocyanatehuman serum albumin conjugate are associated with toluene diisocyanate bronchoprovocation test results. J Allergy Clin Immunol. 1999;104:847-51, http://dx.doi.org/10.1016/ S0091-6749(99)70297-6.

49. Bernstein DI, Korbee L, Stauder T, Bernstein JA, Scinto J, Herd ZL, et al. The low prevalence of occupational asthma and antibody-dependent sensitization to diphenylmethane diisocyanate in a plant engineered for minimal exposure to diisocyanates. J Allergy Clin Immunol. 1993;92(3):387-96, http://dx.doi.org/10.1016/0091-6749(93)90117-X.
50. Robert A, Ducos P, Francin JM, Marsan P. Biological monitoring of workers exposed to 4,4'-methylenediphenyl diisocyanate (MDI) in 19 French polyurethane industries. Int Arch Occup Environ Health. 2007 Apr;80(5):412-22, http:// dx.doi.org/10.1007/s00420-006-0150-3.

51. Sennbro CJ, Lindh CH, Tinnerberg H, Welinder H, Littorin M, Jönsson BA. Biological monitoring of exposure to toluene diisocyanate. Scand J Work Environ Health. 2004 Oct;30(5):371-8, http://dx.doi.org/10.5271/ sjweh.825.

52. Schettgen T, Heinrich K, Kraus T, Gube M. Determination of 2,5-toluylenediamine (2,5-TDA) and aromatic amines in urine after personal application of hair dyes: Kinetics and doses. Arch Toxicol. 2011;85:127-33, http://dx.doi.org/10.1007/s00204-010-0563-3.

This work is available in Open Access model and licensed under a Creative Commons Attribution-NonCommercial 3.0 Poland License - http://creativecommons.org/ licenses/by-nc/3.0/pl/deed.en. 